\title{
Images of environmental management: competing metaphors in focus group discussions of Swedish environmental quality objectives.
}

\author{
Victoria Wibeck
}

\section{Linköping University Post Print}

N.B.: When citing this work, cite the original article.

The original publication is available at www.springerlink.com:

Victoria Wibeck, Images of environmental management: competing metaphors in focus group discussions of Swedish environmental quality objectives., 2012, Environmental Management, (49), 4, 776-787.

http://dx.doi.org/10.1007/s00267-012-9816-7

Copyright: Springer Verlag (Germany) http://www.springerlink.com/

Postprint available at: Linköping University Electronic Press

http://urn.kb.se/resolve?urn=urn:nbn:se:liu:diva-76378 


\title{
Images of environmental management: \\ Competing metaphors in focus group discussions of Swedish environmental quality objectives
}

\author{
Victoria Wibeck, \\ Centre for Climate Science and Policy Research \\ Department of Thematic Studies-Water and Environmental Studies \\ Linköping University \\ 60174 Norrköping \\ Sweden \\ E-mail: victoria.wibeck@liu.se \\ Phone: +4611363285
}

\section{Abstract}

In managing environmental problems, several countries have chosen the management by objectives (MBO) approach. This paper investigates how focus group participants from the Swedish environmental administration used metaphors to describe the mode of organization needed to attain environmental objectives. Such analysis can shed light on how an MBO system is perceived by actors and how it works in practice. Although the Swedish government intended to stimulate broadbased cooperation among many actors, participants often saw themselves as located at a certain "level," i.e., "higher" or "lower," in the MBO system - that is, their conceptions corresponded to a traditional, hierarchical interpretation of MBO. Prepositions such as "in" and "out" contributed to feelings of inclusion and exclusion on the part of MBO actors. However, horizontal metaphors merged with vertical ones, indicating ongoing competition for the right to interpret how the system of environmental objectives should best be managed. The paper concludes that any organization applying MBO could benefit from discussing alternate ways of talking and thinking about its constituent "levels."

Key words: metaphors, social representations, environmental objectives, management by objectives (MBO), sustainable development 
In recent decades, increasing worldwide attention has been paid to attaining sustainable development (Sneddon et al. 2006), and related efforts have motivated new political action strategies in various national contexts, not least in the environmental area (Lundqvist 2004). In several national and international contexts, management by objectives (MBO) is now being used for environmental governance. ${ }^{1}$ This means that to achieve long-term ecological sustainability, environmental objectives are being agreed on by politicians, for subsequent implementation and assessment by civil servants in local, regional, and national contexts (e.g., Edvardsson 2004; Government Bill 2009/10:155; Government of UK 2005; Nilsson et al. 2009). ${ }^{2}$ A main argument for introducing MBO in public environmental management is that the establishment of guiding visions is an efficient way of overcoming problems related to coordinating heterogeneous actors to implement sustainable development programs (Voss et al. 2007). However, such an application of MBO also gives rise to new challenges.

A major governance challenge concerning sustainable development is managing change when power is distributed among many societal actors and across several subsystems (Meadowcroft 2007; Voss et al. 2007). In public environmental MBO, a wide variety of actors operate on local, regional, national, and international scales, in the environmental bureaucracy and other societal sectors. Although the overarching agenda is set by politicians at the national, transnational, and international levels, other actors have the power to choose how to attain the given objectives (Voss et al. 2007). Meadowcroft (2007, p. 308) argues that "navigating in such complex contexts - advancing an ambitious reform agenda when power is fragmented among many actors and subsystems - implies a turn toward a more interactive/reflective mode of governance." Such governance builds on interaction between power centers in defining sustainability objectives and in

\footnotetext{
${ }^{1}$ Countries where MBO is used for public environmental management include Sweden, Finland, the Netherlands, Germany, the United Kingdom, Canada, and Australia.

2 Such national environmental objectives include the Swedish environmental objectives "reduced climate impact," "flourishing lakes and streams," and "zero eutrophication" (http://www.miljomal.nu/english.php), and the Australian objectives "protect threatened species and ecological communities" and "achieve ecologically sustainable management of Australia's water resources and water-dependent ecosystems" (http://environment.gov.au/biodiversity/publications/objectives/pubs/objectives.pdf ).
} 
taking action to achieve them. This, however, does not come about by itself. For interactive/reflective governance to happen, we must encourage reflection "about societal circumstances in order to reassess practices and adjust initiatives" horizontally across society as well as vertically in governments (Meadowcroft 2007, p. 308). In a public environmental MBO system, one relevant social circumstance that affects practices and initiatives would be how actors, when given the power of choosing how to achieve the given objectives, perceive and articulate their own and others' roles and responsibilities in efforts to achieve the objectives.

MBO is fundamentally a hierarchical system, building on the idea that objectives should be formulated at the "top level" of an organization and subsequently percolate through the organization to the "lower levels," at which action should be taken to achieve the objectives (Nilsson et al. 2009; Rogers and Hunter 1992). The present paper focuses on the Swedish system of environmental objectives, which is an incarnation of sectoral responsibility in that it shifts the focus from "viewing environment as a policy domain in its own right to viewing environment as a sector responsibility to be integrated into all economic sectors" (Nilsson et al. 2009, p. 8). In this respect, the Swedish system of environmental quality objectives fits well with the idea of environmental policy integration, which has gained increasing ground in environmental policy and management. Here, the system emphasizes that environmental concerns should be integrated into all societal sectors (Lafferty and Hovden 2003) and that "interactions among actors are central to policy processes" (Nilsson 2005, p. 209).

This paper starts from the assumption that actors operating in a public environmental MBO system find themselves in tension between a hierarchical management model and more horizontal ideals of environmental policy integration and cooperation between various societal actors in efforts to achieve environmental objectives. Understanding how key actors describe and handle this tension is important for the development of steering strategies for attaining sustainable development, since "the attitudes of decision makers are an important part of the complex reality of 
environmental issues and are now recognized as being central to environmental policy formation" (Swaffield 1998, p. 495). The present paper aims to analyze how key actors in the Swedish environmental bureaucracy perceived and communicated their roles and responsibilities in an environmental MBO system. Furthermore, the paper will analyze how these actors perceived the organization in which they worked and the management ideals underlying it. The paper will also examine how they perceived their relationships with other actors and their opportunities for communication across administrative boundaries. In particular, the paper will discuss how the interviewed key actors positioned themselves as actors in the MBO system through their use of metaphorical language.

One critical element of an interactive/reflective approach to governance is the examination of interactions among actors to learn about their interests, perspectives, and capacities (Meadowcroft 2007). The present paper employs focus group interactions between key actors in Swedish public environmental MBO as means to explore how they used metaphorical descriptions to orient themselves in the system of environmental MBO. The focus on language use in general and on metaphors in particular is motivated by the assumption that language "enables and limits the range of practices and interactions in which actors can engage" (Feindt and Oels 2005, p. 166). In the rapidly growing field of discourse analytical studies of environmental policy and management, scholars have highlighted the importance of language use in analyzing "the messy and complex interactions that make up the environmental policy process" (Hajer and Versteeg 2005, p. 176). Such analysis may enhance our understanding of how central concepts such as sustainable development are implemented amidst a constant struggle over their meaning. Discourse analysis can make sense of this struggle, for example, through revealing the role of language in shaping practices (Hajer and Versteeg 2005). From a discourse analytical perspective, language is seen not as a neutral messenger of ideas and interests or as a mere mirror of reality, but as something that can influence the formation of preferences and interests and shape actors' views of the world (Feindt and Oels 2005; Hajer and 
Versteeg 2005). The analysis of metaphors is central to discourse analysis (Hajer and Versteeg 2005), since metaphors are one of the most powerful tools used in producing new knowledge, and thus strongly influence how we conceive of the world around us (Hajer and Versteeg 2005; Harré et al. 1999; Lakoff and Johnson 1980; Swaffield 1998; Varan 1998). Lakoff and Johnson (1980, p. 4) hold that "most of our ordinary conceptual system is metaphorical in nature." In other words, activities that we engage in every day are likely to be cognitively structured by metaphors. Metaphors highlight certain aspects of a phenomenon, concept, or situation while hiding others (Swaffield 1998). In the case of environmental MBO, the use of metaphors may, for example, foreground some relationships between actors while concealing others.

This is not to say, however, that all governance problems can be reduced to language use, or that if only we changed the types of metaphors used, MBO would work more smoothly. Many other factors influence the success of public environmental MBO, such as political will to prioritize the attainment of environmental objectives, allocation of resources (e.g., money, time, and personnel) to formulate objectives and targets, implement action plans, and evaluate results, the clear formulation of goals and targets (Edvardsson 2004), synergies between goals rather than goal conflicts (Wandén 2007), transparency in division of responsibilities (Johansson 2008), and appropriate communication channels (Wibeck 2009a; Wibeck et al. 2006). Nevertheless, identifying and discussing metaphors used by key actors in the environmental bureaucracy to make sense of their day-to-day practices may further the development of interactive/reflective governance. Such governance calls for key actors to reflect on how their patterns of action, their frames and structures, compound persistent problems (Hendriks and Grin 2007; Voss and Kemp 2005). Hendriks and Grin (2007, p. 334) note that "governing for sustainability requires a continuous reconsideration of the practices, structures and outcomes of governance." When the metaphor systems that structure management perceptions are made visible to actors in an environmental bureaucracy, these actors may be empowered to reflect on and hence handle some of the communication problems that arise 
from conflicts between different ways of conceiving the preferred and actual organization of the environmental administration (cf. Marková 1996).

\section{Swedish environmental policy: the system of environmental quality objectives}

In Sweden, the MBO approach was chosen for application in environmental governance in 1999. Since 1999, efforts to achieve sustainability have been channeled through first fifteen and, more recently, sixteen national environmental quality objectives (Government Bill 2009/10:155). ${ }^{3}$ The MBO process demands that objectives be established, their attainment directed, and the results measured (Voss et al. 2007). In Swedish public environmental MBO, the Swedish Parliament determines the environmental objectives and interim targets to be implemented and assessed by civil servants in the appropriate contexts (Edvardsson 2004). One reason advanced by the Swedish government for introducing an MBO structure for environmental policy was that such a structure would bring about increased cooperation to create a better environment:

Environmental quality goals will constitute the basis of a system of management by objectives and results, which in the Government's view is the most effective way of implementing a broad environmental strategy involving participants in all sectors. (Government Bill 1997/98:145, p. 3)

The Swedish system of environmental quality objectives could be regarded as an attempt to tackle what Kettl (2002) identifies as the basic challenge of contemporary public management, i.e., to integrate collaborative, horizontal systems with the hierarchical, specialized, and functional systems that distinguish traditional bureaucracy. The system also presupposes power distribution, in that the agenda for sustainable development set by Parliament is very broad. To attain the overarching goal of sustainable development, power to choose appropriate means for achieving

\footnotetext{
${ }^{3}$ These are: reduced climate impact, clean air, natural acidification only, a non-toxic environment, a protective ozone layer, a safe radiation environment, zero eutrophication, flourishing lakes and streams, good-quality groundwater, a balanced marine environment, flourishing coastal areas and archipelagos, thriving wetlands, sustainable forests, a varied agricultural landscape, a magnificent mountain landscape, a good built environment, and a rich diversity of plant and animal life (http://www.miljomal.nu/Environmental-Objectives-Portal/).
} 
the goal is dispersed among a variety of actors, in the environmental bureaucracy and other societal sectors.

A fairly complex organizational structure has been created to administer the Swedish MBO system. On the one hand, Swedish environmental policy is distinguished by the principle of sectoral responsibility, which is a horizontal attempt to integrate environmental concerns into all societal sectors. More specifically, sectoral responsibility means that all government agencies are given a general responsibility to contribute to achieving the environmental objectives, while some agencies are also assigned specific responsibilities to take measures and assess progress toward particular objectives (Nilsson et al. 2007). On the other hand, the vertical approach of management by objectives is used to organize the system of environmental objectives. In the Swedish environmental MBO system, the government proposes national environmental objectives to be decided upon by Parliament. Implementation of action strategies to attain the objectives, as well as assessment of progress toward the objectives, is undertaken by civil servants at central agencies, county boards, and municipalities. Specific national agencies have been made responsible for the national coordination of each objective (Environmental Objectives Council 2006). In the regional context, the 21 county administrative boards are, under the direct jurisdiction of the national government, responsible for implementing and evaluating the environmental measures taken in their counties. Regional implementation is cross-sectoral, characterized by dialogue with municipal stakeholders from business and other sectors (Ministry of the Environment 2001). The 290 municipalities, which have far-reaching self-governance, for example, possessing some taxation rights, are expected to take responsibility for local implementation of the national objectives. The environmental objectives are not legally binding, and official documents on the environmental quality objectives primarily advocate voluntary measures to achieve the objectives, in combination with economic incentives (Dalhammar 2008). 
Earlier studies have revealed a fragmented image of the system of environmental quality objectives in Sweden. Some researchers have referred to the system as an "effective and communicable way of monitoring and evaluating systematically the overall direction of environmental performance in Swedish society" (Nilsson et al. 2009, p. 8). The long-term approach of the objectives, which span at least one generation, has also been seen as beneficial (Lundqvist 2004). In addition, the Swedish government emphasizes that society strongly supports the environmental quality objectives (Government Bill 2009/10:155). Other studies, however, have identified conflicts between the environmental objectives and other societal objectives (Wandén 2007), unclear roles and responsibilities in the environmental bureaucracy (Johansson 2008), and imprecision in the formulation of the environmental objectives (Edvardsson 2004).

The system of environmental objectives was evaluated in 2009 (SOU 2009:83). In a new Government Bill (2009/10:155), the government proposed among other things that the Environmental Objectives Council, which formerly coordinated efforts to achieve the environmental objectives, should be closed down and its tasks transferred to the Swedish Environmental Protection Agency. Another proposal was that the government, not Parliament, should decide on new interim targets.

Both the original and revised Swedish environmental MBO systems contain many actors with many different roles and responsibilities. Studies have demonstrated that, at least in the initial phase, the actors experienced considerable uncertainty as regards the distribution of responsibilities, and they perceived the organization of the system as far from transparent (Johansson 2008; Riksrevisionen 2005).

\section{Metaphors in environmental management}

Earlier studies have demonstrated that metaphorical language is a salient feature of environmental discourse (e.g., Bell 2005; Harré et al. 1999; Mühlhäusler and Peace 2006; Philippon 2004). The use of metaphors is often regarded as necessary to explain complex environmental phenomena otherwise 
very difficult for non-experts to understand. Among the more famous metaphors is that of "space ship earth" (Boulding 1965), which, according to Princen (2008), is an appropriate metaphor to support global environmental policy in that it connotes a fragile life-support system. Another wellknown metaphor frequently discussed in environmental discourse is that of the "lifeboat" (Hardin 1974), which alludes to Earth's limited capacity to support its population.

The use of metaphors has also been studied in relation to organizations (Alvesson 2002) and organizational change. Some studies have addressed organizational change as a whole (e.g., Abel and Sementelli 2005; Akin and Palmer 2000; Cleary and Packard 1992) while others have studied the use of metaphors in various organizations, such as schools (Argaman 2008; Craig 2005; Hannay 1996) or business enterprises (Dunford and Palmer 1996). In an analysis of how metaphors could be used to improve organizations, Akin and Palmer (2000) stress that although metaphors are figures of speech, they may strongly influence organizational development. Likewise, Abel and Sementelli (2005) argue that metaphors are effective linguistic tools that may reduce uncertainty, stress, and resistance in change processes in an organization. Analyzing the use of metaphors in organizational change may reveal gaps between various actors' values, goals, and practices (Abel and Sementelli 2005). Moreover, when actors vary their metaphors in describing organizational change, such variation could indicate awareness of the official voice of the organizational leadership as well as individual positioning regarding changes in an organization (Argaman 2008).

Metaphorical language is an important and powerful component of human communication, as metaphors "provide new intellectual vistas focusing attention on distinct facets of the perplexities of life" (Varan 1998, p. 58). Metaphors have been demonstrated to play an important role in anchoring abstract concepts in conceivable, well-known categories (Moscovici 1984), a principle that should also apply to attempts to direct efforts to achieve environmental sustainability through generally formulated objectives. Billig and Macmillan (2005, pp. 461-462) point out that "structures of metaphorical meaning shape our understandings but we cease to notice them for their 
meanings operate unconsciously. The effects are ideological and the recovery of metaphorical meaning then becomes a task of critical analysis.” According to Ravetz (2003), human activities are both described and informed by metaphors that embody cultural and social values and thus help shape practice. Hence, Ravetz calls for increased awareness of the prevalence of metaphors.

Several scholars have claimed that metaphorical language is not a question of the uncomplicated transfer of concepts between contexts. Instead, according to Maasen and Weingart (2000), metaphors have a constitutive function in that they alter the new contexts into which they are moved, and are themselves changed by these new contexts. Others argue that metaphors transfer meaning from one context to another, and are themselves a form of recontextualization (Linell 1998a,b; Wee 2005), i.e., a process in which a concept or message is taken out of its original context, and subsequently put into new contexts. In the new context, new meanings may arise, since metaphors bring to the new context "a whole cluster of epistemic as well as political and moral implications" (Maasen and Weingart 2000, p. 21). Drawing on Foucault (1977), Maasen and Weingart (2000, p. 21) argue that "discourse changed by metaphor reorganizes reality. In this way, in the order of discourse, metaphors are effective elements in the interplay of power/knowledge" and "can be described as a principle of arrangement and diffusion of knowledge."

The studies of the use of metaphors cited above all deal with "traditional" metaphors in the sense that one conceptual entity (e.g., "spaceship") is used as a "source" or "vehicle" to understand or represent another conceptual entity (e.g., ecosystem fragility) (cf. Wee 2005). In contrast, the present study focuses on so-called orientational metaphors, which were frequently used by the study's informants. Orientational metaphors are claimed to be of special interest in the analysis of metaphors as they are used non-metaphorically; in other words, they are powerful since speakers rarely reflect on their metaphorical status (Lakoff and Johnson 1980). Lakoff and Johnson (1980) point out that many concepts now used in an abstract sense were originally concrete and physical, especially orientational metaphors that organize a system of concepts in spatial or temporal 
terms: up-down, in-out, fast-slow, and increasing-decreasing. Since orientational metaphors are part of ordinary language, seldom reflected on as metaphors and thus appearing as "natural" ways of perceiving the social world, they are powerful means of structuring the perceptions of environmental management (Lakoff and Johnson 1980). Dyrberg (2009, p. 136) argues that orientational metaphors "form part of our cognitive set-up as power/knowledge devices" and that they "play a political role by bringing together various concerns thus giving them direction and by expressing something abstract ... in terms of something tangible and physical."

Orientational metaphors are often based on the use of prepositions. Prepositions in themselves form perceptual systems that describe dynamic relationships between activities and settings (Pierskalla et al. 2007). In an analysis of spatial prepositions, O'Keefe (1999) argues that prepositions play an important role in how we perceive and talk about spatial and social relationships. For example, prepositions such as "under" or "in" bear connotations of influence, since an object that is perpendicular to another and in contact with it might exert a gravitational force on it, while an entity inside another might be confined by it. In other words, vertical prepositions, such as "down" and "under," can be used metaphorically to connote influence and social status.

In the analysis presented here, I have grouped various spatial terms used metaphorically into the category of orientational metaphors. My analysis includes nouns such as "top," "bottom," or "level," adjectives such as "broad" or "distanced," and verbs such as "reach out" (cf. Landau 1999). In addition, I have included prepositions such as “up," “down," "in,” and "out," which bear metaphorical meanings of (social) influence and social status (O’Keefe 1999).

Method

This study is part of a larger project analyzing communication processes in the system of Swedish environmental quality objectives (see Johansson 2008; Wibeck 2009 a,b; Wibeck et al. 
2006). The analyses presented here are based on data from eight focus group interviews with politicians and civil servants in the Swedish environmental administration. ${ }^{4}$ Sweden was selected as a case, since it is often cited as a frontrunner in environmental policy and implementation (e.g., Meadowcroft 1999; Nilsson and Eckerberg 2007; Wurzel 2002) and ranks high in international comparisons of environmental policy performance (e.g., the Yale Center for Environmental Law and Policy/CIESIN 2006). In international arenas such as the EU and the UN, Sweden has pushed the environmental agenda, for example, in regard to the EU's sustainable development strategy and the Cardiff process (Nilsson et al. 2007). Hence, a case study of Swedish environmental management could be expected to yield lessons relevant to other countries as well (Nilsson et al. 2007), although possible cultural differences should be taken into account.

A focus group is a targeted group interview in which a small number of participants discuss a specific issue, guided by a moderator (e.g., Puchta and Potter 2004; Stewart et al. 2007). In the present study, group size normally ranged from three to six participants. ${ }^{5}$ Focus group methodology was chosen since it lets informants elaborate their arguments, and allows the expression of paradoxes and ambivalence (Marková et al. 2007). A purposive sample of key actors involved in implementing and assessing environmental goal achievement was selected. These actors were local politicians (one focus group including municipal commissioners), civil servants from Swedish municipalities (one focus group including municipal participants who had some experience implementing the system of environmental objectives), county governors (one focus group including participants from various geographical areas of Sweden), civil servants from county boards (two focus groups, one in northern and one in southern Sweden), and civil servants from national agencies responsible for implementing and assessing the national environmental objectives (three focus

\footnotetext{
${ }^{4}$ Other analyses of this data are found in Johansson (2008).

${ }^{5}$ However, in one group (the local politicians) only two participants showed up. This group would, in Toner's (2009) terminology, be regarded as a very small focus group (VSFG). Toner argues that VSFGs may well generate rich data and that even in VSFGs typical group development stages occur, although interaction in larger groups may reflect more variation, distance, and autonomy.
} 
groups, including civil servants who had special responsibility for specific objectives, representing several of the agencies assigned responsibility for particular environmental objectives). In total, 35 interviewees participated in the eight focus groups.

The focus group interviews were initiated by a moderator, who briefly introduced the research project, the focus group method, and the four main discussion themes. The first theme concerned how communication works in the environmental bureaucracy, both at an overall level and especially regarding the assessment of goal achievement. The second theme concerned how management by objectives works in practice. The third theme was explicitly related to the assessment of goal achievement, and concerned the question of what can and should be measured. The fourth theme concerned opportunities for feedback between various actors involved in the system of environmental objectives. After her introduction, the moderator assumed a withdrawn role. The groups were homogeneous in terms of organizational belonging, i.e., all participants in a single group came from the national, regional, or local context. Homogeneous groups were chosen since participants who share certain experiences and opinions are probably more willing to exchange ideas and thoughts in a focus group (Jarrett 1993). However, break characteristics were also evident (Knodel 1993), in that the participants worked with different environmental objectives or in different municipalities, county boards, or central agencies.

The focus group discussions lasted 60-90 minutes. They were tape recorded and transcribed verbatim. The analysis of the use of metaphors was inspired by methods for analyzing communication strategies in focus group data suggested by Marková et al. (2007, ch. 6). The first step was to inventory all instances in which the participants used metaphorical language. Thereafter, a list of all the metaphors and the contexts in which they were used was compiled. Next, the list of metaphors was categorized, i.e., all metaphors were grouped into a category, such as temporal metaphors, metaphors associated with competition, and orientational metaphors. For the purposes of this paper, I have chosen to focus on the 
orientational metaphors, a type of metaphor that, to my knowledge, has seldom been analyzed in relation to environmental management. Nevertheless, I believe that an analysis of the use of orientational metaphors, which "play an essential role by systematizing and directing identification and signification" (Dyrberg 2009, p. 137), could enhance our understanding of how actors in an environmental MBO system perceive their roles and responsibilities in the system.

The interviews were conducted in Swedish, but the quotations cited here have been translated into English and adapted to the conventions of written language.

\section{A hierarchical system}

As noted above, the participants in the present study frequently used orientational, mainly spatial, metaphors to describe the organizations in which they worked. Much of this metaphorical system was expressed through spatial prepositions. The metaphor systems used by the focus group participants often had a clear vertical orientation, characterized by the continuous use of metaphoric dichotomies, such as up-down, top-bottom, and higher levels-lower levels, by all informants irrespective of their professional context. The analysis consequently finds evidence that a vertical metaphor system permeated the thinking of participants situated in national, regional, and local contexts, which is in line with previous observations of MBO systems (Passl 1993) and the idea of a hierarchical system underlying MBO theory (Roth 2009). The following example is taken from a focus group consisting of civil servants from several municipalities.

\section{$\underline{\text { Example } 1^{6}}$}

But isn't it about the lack of a comprehensive view? It is not there all the way-from the government all the way down, sort of. For the municipalities it is difficult to shape a whole when it isn't the case anywhere else. (Local civil servants)

\footnotetext{
${ }^{6}$ The metaphors are indicated in italics.
} 
In the excerpt, the municipal civil servant mirrors the hierarchical idea underlying MBO, locating the government as "up" in the system of environmental objectives, and the municipalities as "down." Objectives are formulated at the national level and are to be communicated "down" through the regional to the local levels. The civil servant expresses concern regarding the lack of a comprehensive view of society, all the way from the top to the very bottom. He argues that if the government, at the top, does not have a comprehensive view, the actors at the local level (understood as the bottom) will experience great difficulties in formulating such a view.

Similarly, the participants in a focus group consisting of local politicians discussed how they had experienced problems when the new MBO system was introduced as part of an earlier local environmental management structure. The following is extracted from a sequence in which the participants discuss how municipalities worked toward environmental objectives when the national MBO system was launched in 1999:

\section{Example 2}

... in some ways it is a problem in this work, in a way, that you work very hard down here, and then they come from up above saying something, and it doesn't really agree ...

(Local politicians)

In Example 2, the politician reflects on the fact that national or regional MBO systems "from above" conflict with pre-existing work on objectives "down" in the local context. "Down" in the municipal context, efforts to achieve environmental objectives had already started when the regional and national objective systems were introduced "from above." Thus, the local politician describes a situation in which local self-determination collides with orders from "up above."

Examples 1 and 2 illustrate the hierarchical idea of $\mathrm{MBO}$ as a pyramid in which decisions are made at the "top" and implementation takes place at the lower "levels" of the bureaucracy. The hierarchical power structure is reinforced by the use of the prepositions "up" and “down," which can be used metaphorically to express relationships of status (O'Keefe 1999). 
Locating an agent "over" other agents in an organization is a way of expressing that the agent who is “over" exerts influence over or controls those who are "under" him or her (O'Keefe 1999). This vertical conception, inherent to the hierarchical construction of the MBO system, is claimed to run counter to the ideals of broad cooperation between actors in various sectors and across administrative boundaries, ideals at the core of Swedish environmental policy (Nilsson et al. 2007).

\section{Positioning oneself in a limited circle of actors}

In addition to the vertical structure discussed above, some spatial representations that recurred throughout the focus group data differed in orientation, i.e., "in" versus "out." The participants conceived of themselves as "inside," while parties such as members of the general public, business sector representatives, or actors in other parts of the environmental bureaucracy regarded themselves as "outside." The following example comes from a focus group consisting of civil servants from several municipalities:

\section{Example 3}

I kind of see that one is very good at formulating lots of objectives, but somewhat poorer at coming up with action strategies that really reach out all the way to the actors who will perform the work. I can also see great shortcomings in the objectives that are being formulated now, in that you haven't actually reached out to the actors. So then not much will get done. (Local civil servants)

The metaphors used by the participant create the image that the MBO actors are locked inside a room and have more or less failed at the strenuous task of "reaching out" to the actors located far from the policy makers formulating the objectives. The prevailing image of the communication situation is one in which the focus group participants are "inside" and the actors they 
wish or need to communicate with are "outside." Much effort was perceived as needed to "reach out" from the environmental administration area to actors in other contexts. For example, participants used spatial metaphors such as "we are far from those who are supposed to implement the objectives" (civil servants from a national agency), or "we, the politicians, or others who work on these [environmental] issues need to be out there talking to people" (local politicians). In this respect, problems communicating with actors in other administrative contexts, or with laypeople, can be attributed to mental and physical distance. The participants position themselves as belonging to different arenas from those of the actors with whom they need to communicate.

Another recurrent theme in the focus group discussions was that the participants positioned themselves and others at certain "levels" of the system, having limited contact with actors at other "levels." This can be seen as an example of the up-down hierarchy discussed earlier. In addition, such talk of levels adds to the participants' repeated construction of a metaphor system of inclusion and exclusion. The following example comes from a group of civil servants from a central authority discussing their relationships with actors in the regional and local contexts:

\section{Example 4}

I don't think that ... at least I have not read anywhere that we are expected to sort of manage the entire chain down to the grassroots level that you talk about. For a start, I think it's impossible. And just like someone here said, when it comes to me, I can affirm that the level of contact is fairly high, and then you expect others to take responsibility for the other levels. But the contacts I have are primarily at our level, that is, the level of central authorities, and in some particular cases, a few private contacts with particular counties and so on, but not in a very welldeveloped way. This means that I must admit that I have a very limited conception of what is going on, even with my own environmental objective at other levels, in the counties. It is true that the county boards report on it in various contexts, but there is not enough time to initiate yourself into everything that is done, at least that's what I think. So I'd better admit that I am 
fairly distanced from any better insight into what happens to the environmental objectives at the local levels.

(Civil servant from a national agency)

In Example 4, the speaker frames his account in line with the other examples above using vertical language. When discussing the actors involved in assessing the environmental objectives, he describes them as located at different levels. In the quotation, the speaker positions himself in a relatively narrow context of actors located at the same level in the system. He claims to have a "very limited conception" of how the environmental objective he is responsible for is handled at other "levels." In other words, he positions himself in a locked-up area "distanced" from the regional and local contexts. He claims to interact mainly with other actors located at the same level as himself, i.e., they are horizontal contacts.

A collective identity is formed as the participants position themselves within a narrow circle of actors. Such collective identity is repeatedly created and reformed through the discursive processes of inclusion and exclusion. Sampedro (1998, p. 128) claims that

Collective entities develop into symbolic realms that, once reified in discourse, confer stability to the subjects' selfidentities. In addition, that discourse is based upon a classification system inter alia. It allows the members of the community to define themselves against the others, understood as those beyond the boundaries of the common social space. Finally, it may also reproduce distinctions between "us" and "them" at the internal level in line with social divisions, relations of power, and domination.

In other words, through the use of metaphors adding to the rhetoric of inclusion, exclusion, and positioning, communication hindrances between actors in different contexts are recreated and maintained. Different administrative contexts are conceived of as located at different levels in a hierarchy, the national level being on top and the local level at the bottom. I argue that the hierarchical construction of the MBO system mirrored in the use of vertical prepositions and metaphors might comprise an obstacle to the properly functioning communication aimed at in 
Swedish environmental policy (Nilsson et al. 2007), since it limits the range of actors identified as relevant to communication.

The use of the "chain" metaphor indicates, however, the existence of vertical connections between the different levels. The "chain" metaphor not only lets us conceive of the MBO system in hierarchical terms, as a pyramid of actors separated from each other, but also connotes that the levels are interrelated in one way or another. In Example 4, the speaker depicts the "chain" of actors as extending from those located at a "high" level, supposedly that of national authorities, "down to the grassroots level," which may be interpreted as comprising actors in the various local contexts. Elsewhere in the discussion, the participants in the same focus group talked about their responsibility to "report up to the Parliament and the government"; in other words, the top of the "chain" was conceived as consisting of politicians in the national context. Nevertheless, Example 4 indicates that, in practice, communication arenas are primarily aimed at the same "level" as that at which the actors position themselves.

\section{Positioning oneself in a broad, heterogeneous circle of actors}

In contrast to the dominant way of talking about the organization of the environmental objectives system in terms of "up" versus "down" and "in" versus "out," there were also patterns of a counterdiscourse emphasizing cooperation, networking, and similarities. The metaphor "broad" was frequently used in such sequences, as in the following example from a focus group consisting of civil servants from various county boards. The sequence concerns working teams that helped formulate regional environmental objectives. The teams consisted of stakeholders from the regional and local contexts.

\section{Example 5}


Participant A: How broadly were those groups composed? Were there companies and municipalities and NGOs?

Participant B: Yes, there was broad-based representation. When we had decided on the objectives last autumn, we arranged a conference lasting an entire day to which we invited [participants] broadly [from across] the whole county—NGOs, companies, municipalities, everyone. ... We emphasized that we wanted to have the municipalities as actors in those working teams.

(Civil servants from county boards)

The image conveyed by this example is one of horizontality, in which achieving working group breadth is itself an aim. In contrast to the vertical system of metaphors described above, aspects of differences in status are concealed in the horizontal metaphor, while aspects of cooperation are highlighted. Arguably, one promise of the Swedish system of environmental objectives lies in the broad-based cooperation between actors representing various social sectors (Government Bill 2000/01:130; Lundqvist 2004). As previously noted, the government's intention when launching the system of environmental objectives was to implement "a broad environmental strategy involving participants in all sectors" (Government Bill 1997/98:3). Moreover, the Swedish MBO system is prefaced with the slogan "Allas ansvar" (everyone's responsibility). The line of reasoning in the quotation above would thus be in line with governmental intentions.

When examining the entire data corpus, it was evident that opposing types of metaphors were expressed in the focus group discussions. None of the focus groups used only horizontal or only vertical metaphors in talking about the organization of the environmental administration. Instead, there was a constant mix of the two types of metaphors, the two metaphor systems sometimes competing and sometimes coexisting in the focus group data. In some instances, the participants explicitly reflected on the different metaphor systems, expressing a preference for the horizontal system while lamenting that the vertical system is what is generally employed in 
practice. I interpret such reflection to play an important role in handling communication problems in managing environmental objectives, as is further developed below.

\section{Discussion}

The examples quoted here illustrate the inherent conflict in the Swedish system of environmental quality objectives between the national political vision of broad-based cooperation among a wide range of actors and the necessity of instituting measures in all policy areas, on the one hand (Government Bill 2004/05:150; Nilsson et al. 2007), and the hierarchical organizational ideas underlying MBO as a steering technique, on the other. Management theorists, however, increasingly accept that managers should operate both across organizations and within hierarchies (Agranoff and McGuire 2003). Earlier studies have suggested that the fundamental challenge of contemporary public management lies in the development of systems and people capable of integrating horizontal approaches and traditional vertical, specialized management systems (Kettl 2002; Weber et al. 2007). However, the analyses reported in the present paper suggest that the government's horizontal intentions were often overshadowed, and that the hierarchical construction of the MBO system largely structured the thinking of the focus group participants. The major part of the metaphorical descriptions used by the participants when discussing the organization of the system of environmental objectives referred to environmental management as a hierarchical, vertical system with a "top" and a "bottom," much in line with textbook conceptions of MBO (cf. Passl 1993; Rogers and Hunter 1992).

According to metaphor theory as discussed above (see the section "Metaphors in environmental management"), the use of vertical metaphors not only reflects but may also help confirm and reproduce the conception of a system of environmental quality objectives as a hierarchical management system. In my view, the use of vertical metaphors may constitute a mental 
constraint to successful governance for sustainable development, in that it helps maintain and recreate a hierarchical order constructed by the $\mathrm{MBO}$ technique, in which arenas for communication are scarce, and in which actors at "lower levels" of the hierarchy have limited opportunities to influence decisions and collaborate with actors at "higher levels." Lakoff and Johnson (1980) argue that spatial metaphors tacitly ascribe values; for example, the word "up," when used metaphorically, is usually given a positive connotation. Following Lakoff and Johnson's argument (1980) that spatial metaphors have a coherent structure, and building on the assumption that "good is up," the more influential an actor is, the higher the level at which s/he can be assumed to be located. ${ }^{7}$ For example, on some occasions, the municipal civil servants and local politicians participating in the focus groups positioned themselves "down" in the system, located at a lower level than actors from the county boards or national agencies. This indicates a perception of a limited ability to act and exert influence, which is in contrast to the independent jurisdictional role of Sweden's municipalities in relation to the government, the government's regional spokespeople (i.e., the county boards), and the national agencies.

The use of metaphors could be interpreted as one strategy for creating and maintaining social representations (cf. Linell 2001; Moscovici 1984). ${ }^{8}$ In the focus group data, the use of metaphors was a common communication strategy used to depict ideas of environmental management in concrete terms, i.e., to reproduce the concept as an image (cf. Moscovici, 1984), for example, as a pyramid, or as different levels located vertically above each other. According to Moscovici, such images may subsequently become disengaged from the ideas or concepts with which they were originally connected, and with time come to be treated as "elements of reality" rather than as "elements of thought" (Moscovici 1984, p. 40). Given this process, it is obvious that

\footnotetext{
${ }^{7}$ Even though Lakoff and Johnson's (1980) analysis is of the English language, similar expressions exist in Swedish, with similar value loadings.

${ }^{8}$ The concept of social representations could be defined as "a system of values, ideas and practices with a twofold function: first to establish an order which will enable individuals to orient themselves in their material and social world and to master it; and secondly to enable communication to take place among the members of a community by providing them with a code for naming and classifying unambiguously the various aspects of their world and their individual and group history" (Moscovici 1973:xiii).
} 
the metaphors used to describe the organization of a system of environmental quality objectives strongly influence how the actors will understand the system and act within it. Nevertheless, one should note that processes of metaphorically recreating a hierarchical, exclusive management system are seldom conscious. Moscovici (1984) points out that social representations gain their power from being unconscious, from leading "a life of their own" (Moscovici 1984, p. 13). Once the representations have become established, or conventionalized, they are difficult to resist. They become socially shared knowledge that is seldom questioned, and the power of such representations lies in their unquestioned status. Not until we begin to reflect on these representations_-perhaps in a critical situation — can we talk about, challenge, and change them (Bauer and Gaskell 1999). In the words of Marková (1996, p. 180),

As people are born into their social environment, they take it as much for granted as their natural and physical environments. ... Yet, people are also agents. They have specific ways of understanding, communicating and acting upon their ontological realities. Once these realities engage their thought, people no longer re-produce and re-cycle their social environment unconsciously or automatically. They also cognize and experience it with awareness. In other words, they not only reproduce their ontological realities but they also engage in epistemological processes and, as a result, they change their ontological realities by acting upon them.

In line with Marková's line of thought, I argue for the necessity of reflecting on and discussing the metaphors and social representations that form the views and understandings of the relevant actors in the environmental objectives system (cf. Bauer and Gaskell 1999). Reflection on the metaphors structuring environmental management activities would, among other things, help those involved to handle communication problems that arise from the different conceptions held by the different actors involved. In this regard, it is worth noting that the analyses reported here indicate variations in the types of metaphors used by the informants. Even though vertical metaphors were the ones most frequently used in the focus group discussions, they did merge with horizontal metaphors. On some occasions, different participants used different types of metaphors, while on others, both horizontal and vertical metaphors could be found in the speech of a single focus group 
participant. I interpret this as indicating negotiation about how the system of environmental objectives should best be managed.

In some parts of the focus group discussions, participants emphasized the opportunities involved when working horizontally across administrative and sectoral borders. This is in line with how Meadowcroft (2007) suggests taking advantage of the distribution of power in governance for sustainable development. Diffusion of power need not be seen as a problem; instead, it can be seen as an opportunity, since it "establishes many channels for information to flow [through], and many ways for feedback from social/environmental interactions to be articulated” (Meadowcroft 2007, pp. 306-307). Nevertheless, I argue that for such horizontal communication efforts to realize their full potential, the structural constraints of the organization need to be taken into account along with the psychological constraints discussed above in relation to the vertical metaphors dominating the discourse of the participants. Are the actors given enough and appropriate resources to participate in dialogues with actors from "outside" their own sectors and administrative "levels"? Do relevant communication fora exist? Are mandates for different actors clearly articulated?

In conclusion, I argue that critical reflection on language use needs to go hand in hand with critical reflection on how best to organize public management systems to achieve sustainable development. More research is needed into the implications of combining the aim of involving a large network of actors in attempts to achieve environmental objectives with a hierarchical MBO system that organizes actors according to vertical dimensions of power and influence.

On a more practical level, I argue that efforts to achieve environmental objectives will benefit from attempts to find new ways of involving relevant actors, and to identify more fora for cross-cutting communication between actors from different societal sectors and "levels" in the environmental administration. Such attempts should, in my view, be complemented with more research into the types of metaphors that would support efficient environmental management. Furthermore, MBO organizations would benefit from the active stimulation of discussion among all 
organizational actors concerning alternate ways of thinking and talking about "levels" in the organization. It is plausible that such endeavors might, with time, alter the social representations of a system of environmental objectives, i.e., how it is conceived of and anchored among the actors involved in implementing and assessing the objectives.

\section{Acknowledgements}

This paper was made possible by a grant from the Swedish Environmental Protection Agency for the research program Assessment of Environmental Goal Achievement under Uncertainty (no. I-37-03). The author wishes to thank Gunilla Öberg and Madelaine Johansson for productive discussion and collaboration throughout the study. Special thanks are extended to Madelaine Johansson, who conducted the focus groups reported on here. Anna Larsson, who now works at the County Board of Södermanland, also contributed to the initial analysis of the material, for which she is warmly acknowledged. The author wishes to thank Anders Grimvall, Claudia Libiseller, Per Milberg, Nico Stehr, Sofie Storbjörk, Lars Westerberg, and three anonymous reviewers for their valuable comments on earlier drafts.

\section{References}

Abel C, Sementelli F (2005) Evolutionary critical theory, metaphor, and organizational change. Journal of Management Development 24:443-458

Agranoff R, McGuire M (2003) Collaborative public management: new strategies for local governments. Georgetown University Press, Washington D.C., 202 pp

Akin G, Palmer I (2000) Putting metaphors to work for change in organizations. Organizational Dynamics 28:67-79. 
Alvesson M (2002) Understanding organizational culture. Sage, London, 214 pp

Argaman E (2008) In the same boat? On metaphor variation as mediating the individual voice in organizational change. Applied Linguistics 29:483-502

Bauer M, Gaskell G (1999) Towards a paradigm for research on social representations. Journal for the Theory of Social Behaviour 29:163-186

Bell D (2005) Environmental learning, metaphors and natural capital. Environmental Education Research 11:53-69

Billig M, MacMillan K (2005) Metaphor, idiom and ideology: the search for "no smoking guns" across time. Discourse and Society 16:459-480

Boulding K (1965) Earth as a space ship. http://earthmind.net/earthmind/docs/boulding-1965.pdf. Accessed 25 March 2010

Cleary C, Packard T (1992) The use of metaphors in organizational assessment and change. Group and Organization Management 17:229-241

Craig C (2005) The epistemic role of novel metaphors in teacher's knowledge constructions of school reform. Teachers and Teaching: Theory and Practice 11:195-208

Dalhammar C (2008) Miljömålen och miljöbalken: möjligheter till rättsligt genomdrivande av miljömål [The environmental quality objectives and the environmental code: opportunities for legal implementation of environmental objectives]. IIIEE Report 2008:1. The International Institute for Industrial Environmental Economics, Lund University, Lund, Sweden Dunford R, Palmer I (1996) Metaphors in popular management discourse: the case of corporate restructuring. In: Grant D, Oswick C (eds) Metaphors and organizations. Sage, London, pp 95-109 Dyrberg TB (2009) What is beyond right/left? The case of New Labour. Journal of Political Ideologies 14:133-153 
Edvardsson K (2004) Using goals in environmental management: the Swedish system of environmental objectives. Environmental Management 34:179-180

Environmental Objectives Council (2006) Responsible authorities. Environmental Objectives Portal. http://www.miljomal.nu/Environmental-Objectives-Portal/Undre-meny/Who-does-what/ Accessed 20 September 2011

Feindt P, Oels A (2005) Does discourse matter? Discourse analysis in environmental policy making. Journal of Environmental Policy and Planning 7:161-173

Foucault M (1977) The history of sexuality, Vol. 1: The will to knowledge. Penguin, Harmondsworth, UK, 168 pp

Government Bill 1997/98:145, Svenska miljömål: miljöpolitik för ett hållbart Sverige [Swedish environmental quality objectives: an environmental policy for a sustainable Sweden]. http://www.regeringen.se/content/1/c4/13/05/4008ccd5.pdf. Accessed 25 March 2010 Government Bill 2000/01:130, Svenska miljömål: delmål och åtgärdsstrategier [The Swedish environmental objectives: interim targets and action strategies]. http://www.regeringen.se/content/1/c4/11/97/7808aab9.pdf. Accessed 15 February 2010 Government Bill 2004/05:150, Svenska miljömål: ett gemensamt uppdrag [The Swedish environmental objectives: a common mission]. http://www.regeringen.se/content/1/c6/04/41/28/77c488d4.pdf. Accessed 10 September 2011 Government Bill 2009/10:155, Svenska miljömål: för ett effektivare miljöarbete [Swedish environmental objectives: for a more efficient work for the environment]. http://www.sweden.gov.se/content/1/c6/14/24/56/dca35b38.pdf. Accessed 1 April 2010 Government of UK (2005) The UK Government Sustainable Development Strategy. http://www.defra.gov.uk/publications/files/pb10589-securing-the-future-050307.pdf . Accessed 26 September 2011 
Hajer M, Versteeg W (2005) A decade of discourse analysis of environmental politics:

achievements, challenges, perspectives. Journal of Environmental Policy and Planning 7:175-184

Hannay L (1996) The role of images in the secondary school change process. Teachers and Teaching 2:105-121

Hardin G (1974) Lifeboat ethics: the case against helping the poor. The Garrett Hardin Society website.

http://www.garretthardinsociety.org/articles/art_lifeboat_ethics_case_against_helping_poor.html. Accessed 1 February 2010

Harré R, Brockmeier J, Mühlhäusler P (1999) Greenspeak: a study of environmental discourse. Sage, Thousand Oaks, CA, 204 pp

Hendriks C, Grin J (2007) Contextualizing reflexive governance: the politics of Dutch transitions to sustainability. Journal of Environmental Policy and Planning 9:333-350

Jarrett R (1993) Focus group interviewing with low-income minority populations: a research experience. In: Morgan D (ed) Successful focus groups: advancing the state of the art. Sage, Newbury Park, CA, pp 184-201

Johansson M (2008) Barriärer och broar: kommunikativa villkor i det svenska miljömålsarbetet [Barriers and bridges: communication conditions within the Swedish environmental objectives implementations process] PhD dissertation, Linköping Studies in Arts and Science no. 469, Linköping University, Linköping, Sweden, 273 pp

Kettl D (2002) The transformation of governance: public administration for twenty-first century America. Johns Hopkins University Press, Baltimore, MD, 204 pp

Knodel J (1993) The design and analysis of focus group studies: a practical approach. In: Morgan D (ed) Successful focus groups: advancing the state of the art. Sage, Newbury Park, CA, pp 35-50 
Lafferty W, Hovden E (2003) Environmental policy integration: towards an analytical framework. Environmental Politics 12:1-22

Lakoff R, Johnson M (1980) Metaphors we live by. University of Chicago Press, Chicago, 242 pp Landau B (1999) Multiple geometrical representations of objects in languages and language learners. In: Bloom P, Peterson M A, Nadel L, Garrett MF (eds) Language and space. MIT Press, Cambridge, MA, pp 317-363

Linell P (1998a) Approaching dialogue: talk, interaction and contexts in dialogical perspectives. John Benjamins, Amsterdam, 330 pp

Linell P (1998b) Discourse across boundaries: on recontextualizations and the blending of voices in professional discourse. Text 18:143-157

Linell P (2001) A dialogical conception of focus groups and social representations. In: Sätterlund Larsson U (ed) Socio-cultural theory and methods: an anthology. University of Trollhättan/Uddevalla, Department of Nursing, Trollhättan, Sweden, pp 163-206

Lundqvist L (2004) Sweden and ecological governance: straddling the fence. Manchester University Press, Manchester, UK, 246 pp

Marková I (1996) Towards an epistemology of social representations. Journal for the Theory of Social Behaviour 26:177-196

Marková I, Grossen M, Linell P, Salazar Orvig A (2007) Dialogue in focus groups: exploring socially shared knowledge. Equinox, London, 243 pp

Maasen S, Weingart P (2000) Metaphors and the dynamics of knowledge. Routledge, London and New York, $185 \mathrm{pp}$

Meadowcroft J (1999) The politics of sustainable development: emergent arenas and challenges for political science. International Political Science Review 20:219-237 
Meadowcroft J (2007) Who is in charge here? Governance for sustainable development in a complex world. Journal of Environmental Policy and Planning 9:299-314

Ministry of the Environment (2001) The Swedish environmental objectives-interim targets and action strategies. Summary of Government Bill 2000/01:130. http://www.miljo.regeringen.nu. Accessed 3 March 2010

Moscovici S (1973) Foreword. In: Herzlich C (ed) Health and illness: a social psychological analysis. Academic Press, London, pp ix-xiv

Moscovici S (1984) The phenomenon of social representations. In: Farr R, Moscovici S (eds) Social representations. Cambridge University Press, Cambridge, UK, pp 3-69

Mühlhäusler P, Peace A (2006) Environmental discourses. Annual Review of Anthropology $35: 457-479$

Nilsson M (2005) Learning, frames and environmental policy integration: the case of the Swedish energy policy. Environmental and Planning C: Government and Policy 23:207-226 Nilsson M, Eckerberg K (eds) (2007) Environmental policy integration in practice: shaping institutions for learning. Earthscan, London, $172 \mathrm{pp}$

Nilsson M, Eckerberg K, Persson Å (2007) Introduction: EPI agendas and policy responses. In: Nilsson M, Eckerberg K (eds) Environmental policy integration in practice: shaping institutions for learning. Earthscan, London, pp 1-24

Nilsson M, Eklund M, Tyskeng S (2009) Environmental integration and policy implementation: competing governance modes in waste management decision making. Environment and Planning C: Government and Policy 27:1-18

O'Keefe J (1999) The spatial prepositions in english, vector grammar, and the cognitive map theory. In: Bloom P, Peterson MA, Nadel L, Garrett MF (eds) Language and space. MIT Press, Cambridge, MA, pp 277-316 
Passl W (1993) Can management by objectives and total quality management be reconciled? Total Quality Management 4:135-141

Philippon D (2004) Conserving words: how American nature writers shaped the environmental movement. University of Georgia Press, Athens, GA, 373 pp

Pierskalla C, Siniscalchi J, Selin S (2007) Using events as a mapping concept that complement existing ROS methods. Leisure Science 29:71-89

Princen T (2008) Notes on the theorizing of global environmental politics. Global Environmental Politics 8:1-5

Puchta C, Potter J (2004) Focus group practice. Sage, London, 174 pp

Ravetz J (2003) Models as metaphors. In: Kasemir B, Jaeger J, Jaeger C (eds) Public participation in sustainability science: a handbook. Cambridge University Press, Cambridge, UK, pp 62-77

Rogers R, Hunter J (1992) A foundation of good management practice in government: management of objectives. Public Administration Review 52:27-39

Riksrevisionen (2005) Miljömålsrapporteringen: för mycket och för lite [Environmental objectives reporting - too much and too little]. RiR 2005:1, Riksdagstryckeriet, Stockholm, 87 pp

Roth W (2009) Is management by objectives obsolete? Global Business and Organizational Excellence 28:36-43

Sampedro V (1998) Grounding the displaced: local media reception in a transnational context. Journal of Communication 48:125-143

Sneddon C, Howarth R, Norgaard R (2006) Sustainable development in a post-Brundtland world. Ecological Economics 57:253-268

SOU 2009:83, Sweden's environmental objectives: new perspectives. http://www.sweden.gov.se/content/1/c6/13/55/25/8ae6a419.pdf. Accessed 2 April 2010 
Stewart D, Shamdasani P, Rook D (2007) Focus groups: theory and practice, 2nd ed. Sage, Thousand Oaks, CA, 188 pp

Swaffield S (1998) Frames of reference: a metaphor for analyzing and interpreting attitudes of environmental policy makers and policy influencers. Environmental Management 22:495-504 Toner J (2009) Small is not too small: reflections concerning the validity of very small focus groups (VSFGs). Qualitative Social Work 8:179-192

Varan D (1998) The cultural erosion metaphor and the transcultural impact of media systems. Journal of Communication 48:58-85

Voss J, Kemp R (2005) Sustainability and reflexive governance: incorporating feedback into social problem solving. Paper presented at ESEE Conference, Lisbon, 14-17 June. Voss J, Newig J, Kastens B, Monstadt J, Nolting B (2007) Steering for sustainable development: a typology of problems and strategies with respect to ambivalence, uncertainty and distributed power. Journal of Environmental Policy and Planning 9:193-212

Wandén S (2007) Miljömål och andra önskemål: en studie av synergier och konflikter [Environmental objectives and other wishes: a study of synergies and conflicts]. Report no. 5747. Naturvårdsverket, Stockholm, 86 pp

Weber E, Lovrich N, Gaffney M (2007) Assessing collaborative capacity in a multidimensional world. Administration \& Society 39:194-220

Wee L (2005) Constructing the source: metaphor as a discourse strategy. Discourse Studies 7:363384

Wibeck V (2009a) Communicating uncertainty: models for communication and the role of science in the assessment of environmental goal achievement. Journal of Environmental Policy and Planning 2:87-102 
Wibeck V (2009b) Communicative challenges in the assessment of progress towards environmental quality objectives. Journal of Science Communication 8(2):A01

Wibeck V, Johansson M, Larsson A, Öberg G (2006) Communicative aspects of environmental management by objectives: examples from the Swedish context. Environmental Management $37: 461-469$

Wurzel R (2002) Environmental policy-making in Britain, Germany and the European Union: the Europeanisation of air and water pollution control. Manchester University Press, Manchester, 318 pp

Yale Center for Environmental Law and Policy/Center for International Earth Science Information Network at Columbia University (2006) Pilot 2006 Environmental Performance Index. Yale Center for Environmental Law and Policy, New Haven, CT 